\title{
Lichen diversity in geothermal area of Kamojang, Bandung, West Java, Indonesia and its potential for medicines and dyes
}

\author{
JOKO KUSMORO ${ }^{1}$, IIN SUPARTINAH NOER ${ }^{1}$, MUHAMAD FEISAL JATNIKA ${ }^{2}$, RIRIN EKA PERMATASARI ${ }^{3}$, \\ RUHYAT PARTASASMITA ${ }^{1, \bullet}$ \\ ${ }^{1}$ Department of Biology, Faculty of Mathematics and Natural Sciences, Padjadjaran University. J1. Raya Bandung-Sumedang Km 21, Jatinangor, \\ Sumedang 45363, West Java, Indonesia. `Email: rp2010rikkyo@gmail.com; ruhyat.partasasmita@unpad.ac.id. \\ ${ }^{2}$ Undergraduate of Biology Program Study Faculty of Mathematics and Natural Sciences, Padjadjaran University. \\ Jl. Raya Bandung Sumedang Km. 21, Jatinangor, Sumedang 45363, West Java, Indonesia \\ ${ }^{2}$ Environmental Study Postgraduate Program, Padjadjaran University. Jl. Sekeloa Selatan I, Bandung 40134, West Java, Indonesia
}

Manuscript received: 28 June 2018. Revision accepted: 18 November 2018.

\begin{abstract}
Kusmoro J, Noer IS, Jatnika MF, Permatasari RE, Partasasmita R. 2018. Lichen diversity in geothermal area of Kamojang, Bandung, West Java, Indonesia and its potential for medicines and dyes. Biodiversitas 19: 2335-2343. The study of lichens diversity in Kamojang, West Java was conducted by survey in geothermal field area following the line transect $6 \mathrm{~km}$ along to the East, North West and south from the Power House of Geothermal Power Plant. The lichen samples were taken from bark, soil, and stone. Lichen identification was done by morphological, anatomy and chemical analysis. Dyes potency of Parmotrema and Usnea test using ammoniac fermentation was done in Plant Taxonomy Laboratory of Department Biology, Faculty of Mathematics and Natural Sciences, University of Padjadjaran. The survey has successfully collected 133 species of lichens, belong to 62 genera and 17 families. Parmeliaceae was found as dominant groups, consisting of 33 species and other co-dominant groups are Graphidaceae and Lobariaceae with 24 species and 8 species, respectively. Most lichens in Kamojang geothermal area belong to Ascomycetes, only one Basidiomycetes such as Dictyonema sericeum (Sw.) which found at Kawah Manuk (Manuk crater) area. The rare species of lichens such as Usnea longissima Ach, was found at Pine forest in Arboretum $6 \mathrm{~km}$ south of Powerhouse of Kamojang geothermal. Chemical analysis and literature study for Lichenic acid contains was done and generally, atranorin, usnic acid, barbatic and lecanoric acid was found in lichens samples. Amoniac fermentation result showed that Parmotrema tinctorum produced brownish red, red and purple, which occurred within 1 week to 5 weeks after fermentation. While Usnea produced variety of brown color, which occurred within 5 days up to 4 weeks after fermentation. Lichen species containing some medical properties are Bulbothrix, Cladonia and Usnea. While lichens having dyes properties are Hypogymnia, Lobaria, Peltigera, Usnea, and Parmotrema.
\end{abstract}

Keywords: Dye, fermentation, Kamojang, lichen, lichenic acid, medicine

\section{INTRODUCTION}

Kamojang Geothermal Area, which is recognized as mountain tropical rain forest, is one of Natural Conservation and Tourism forest in West Java. It is well known as hilly area with beautiful view. It has crater and hot spring water for medical purposes and the source of Geothermal Energy. Kamojang is also natural forest with high diversity of plant, mosses, and lichens. Lichens have the symbiotic phenotype with nutritious fungi and are also associated with algae (Noer 2013; Ardelean et al. 2015; Balabanova et al. 2014; Onuț-Brännström 2017). These are an outstanding group, exploiting a wide range of habitats throughout the world and dominating about $8 \%$ of terrestrial ecosystems. They have a varied chemical contains, which are useful as medicines (Noer et al. 2013 Onuț-Brännström 2017). Lichens contain secondary compounds that are abundant in most lichen thalli. Different lichens produce a wide variety of metabolite compounds, most of which are unique to lichens (Noer et al. 2006). It is suspected that almost $50 \%$ of species of lichens have antibiotic properties (Vartia 1973; Malhotra et al. 2007; Crawford 2015). Lichen compounds have been found to act as anti-tumor agents, antibiotics, and antiinflammatories (Bayir et al. 2006; Rezanka and Dembitsky 2006; Bessadóttir 2014). Some of the most widely studied lichen compounds are usnic acid, vulpinic acid, atranorin, and protolichesterinic acid (Asahina and Shibata 1954; Fazio et al. 2007; Crawford 2015; Salgado 2018). Usnic acid is found in large quantities in Usnea spp., as well as in several other lichen genera.

It is well known that a long time ago lichens have been widely used by people such as for medicine, pollution bioindicator, perfume, decoration, and dye (Ingolfsdottir et al. 2002; Kaasalainen 2012; Vicol 2016; Tarasova et al. 2017). Lichens as natural dye sources have been used since long ago. The purple color (orchil) was firstly reported from Roccella spp. through ammoniac fermentation. The purple color of Roccella had historic importance as the "Royal Purple" in Europe before $19^{\text {th }}$ century and was not been used anymore when synthetic dye substance was found.

Genus Parmotrema is foliose lichen that belongs to Parmeliaceae group. The genus characteristic is the absence of reticular maculate and pseudocyphella. An erhizinate marginal zone of the lower surface is more than $1 \mathrm{~mm}$ 
(Noer 2013). Several Parmotrema species from Himalayas can produce colors with the help of ammonia fermentation method (Shukla et al. 2014). Livelihoods of natural dyes from lichen Parmotrema are very interesting and will be important in the use of dyes that are environmentally friendly in industry in order to reduce the pollution of water/river by dyes from industry. $\square$

The diversity of lichen in this area has been reported by Noer et al. (2006) and Noer and Rani (2007), but only one species has been used as medicine i.e. Usnea barbata, no mentioning about the species has potential for dyes. The continuous survey was done in this area to collect some species, which has potential use for medicine and dyes. Our purpose from the study were: (i) to assess the diversity and distribution of lichens in Kamojang Geothermal Area, (ii) to indicate several lichens, which could potentially be used as medicine and dyes, (iii) to analyse the lichens acids (secondary metabolites) in potential lichen genus for medicine and dyes, (iv) to monitor color produced by Parmotrema and Usnea using ammonia fermentation.

\section{MATERIALS AND METHODS}

\section{Study area}

Kamojang area belonging to mountain tropical forest is located at Laksana village, Ibun Sub-district, Bandung
District, West Java, approximately $45 \mathrm{~km}$ southeast of Bandung City. The research area is located on latitude of $7^{\circ} 8^{\prime} 23.13^{\prime \prime} \mathrm{S} 107^{\circ} 47^{\prime} 10.36^{\prime \prime} \mathrm{E}$ to $7^{\circ} 00^{\prime} 00^{\prime \prime} \mathrm{S} 107^{\circ} 00^{\prime} 00^{\prime \prime} \mathrm{E}$ with altitude 1300-1700 above sea level (Figure 1). This exploration was held from April 2016 to August 2017

The microclimate was recorded that the range of temperature ranging from $18^{0} \mathrm{C}$ to $26,26^{0} \mathrm{C}$, while the humidity was from $56.13 \%$ to $78 \%$ and light intensity had 2387 lux to 6748 lux.

\section{Sampling}

The research material was lichen specimens from Kamojang geothermal area. The lichen collection in the study area was taken with survey method at $6 \mathrm{~km}$ transects towards four cardinal points $(\mathrm{N}, \mathrm{E}, \mathrm{W}, \mathrm{S})$ from the Power House of Geothermal Power Plant as the center point. The sample was taken from bark along the road and stone in the study area. Dry specimens were stored in paper bags and wet specimens were needed to be dried first to prevent molding. The specimens were then moistened, pressed flatly between boards, dried and placed on paper packets ( 3 $\mathrm{x} 4$ inches) or on small boxes. $\square$

\section{Lichen identification}

Identification of lichens was conducted by: (i) Determine the growth form; foliose, squamulose, crustose or fructocose. These characters are important in separating

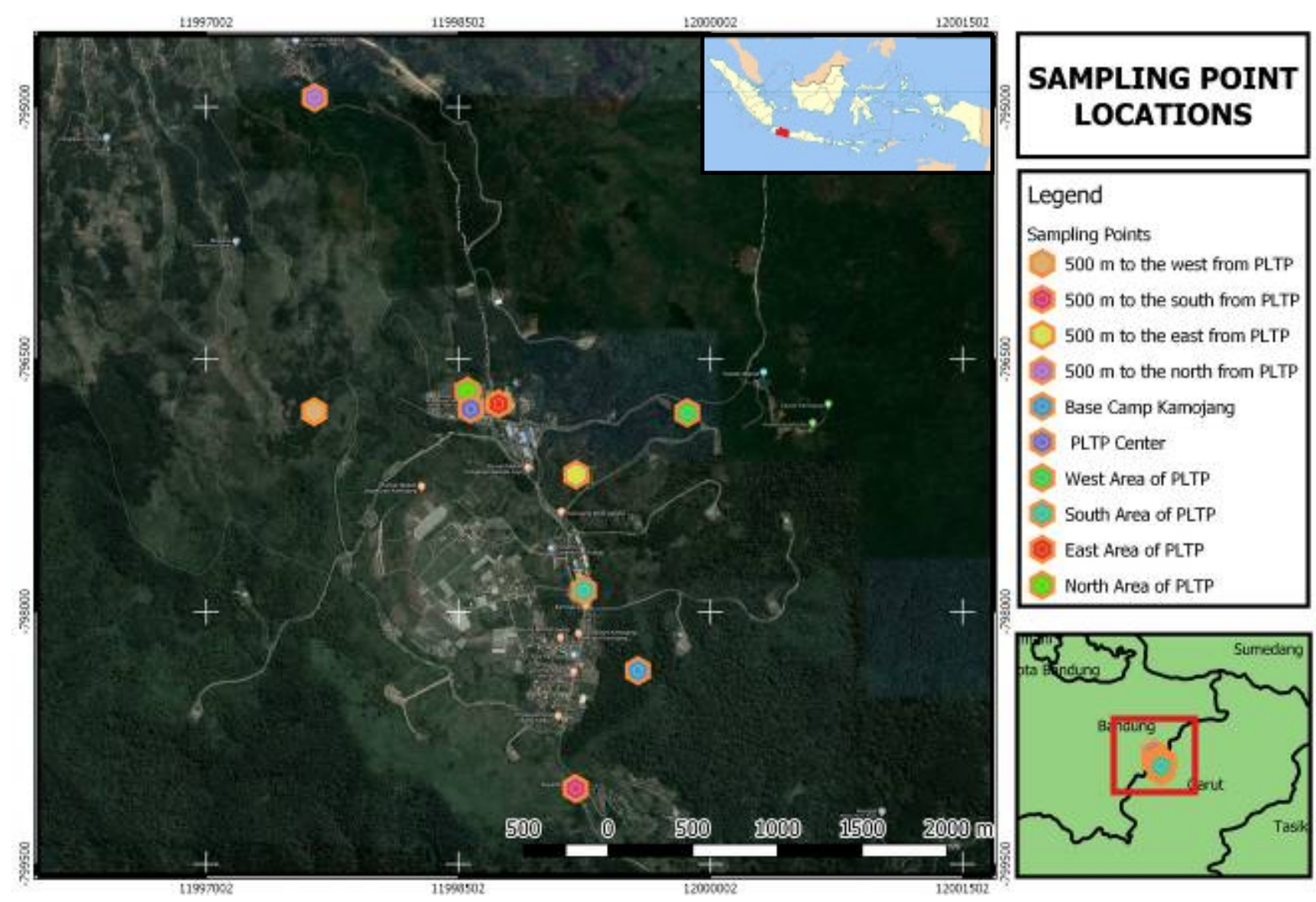

Figure 1. Maps of the research in Kamojang geothermal area, Bandung, West Java, Indonesia 
genera. (ii) Checking the presence of soredia or isidia with a hand lens. These are by far the two most important characters used in identifying lichens at the species level and must be recognized without any doubt. Presence of cilia and the condition of lower side should also be noted. (iii) Chemical test in lichen was used i.e color test and crystal test.

A color test was made simply by applying a drop of reagent on the thallus surface or exposed medulla. If the test is positive, there will be a rapid color change, usually red or yellow; if it is negative nothing will happen. Three different reagents were used, i.e., calcium hypochlorite (bleaching powder, abbreviated $\mathrm{C}$ ), potassium hydroxide (caustic lye abbreviated $\mathrm{K}$ or $\mathrm{KOH}$ ) and paraphenylenediamine $(\mathrm{P})$. The $\mathrm{K}+$ yellow test caused by atronin.

In a crystal test, the acid was dissolved from small fragments of thallus with acetone, and the remainder of crude residue was recrystallized from various reagents on a microscope slide. The reagents in common use are abbreviated as follows and mixed in the volume ratios including: (i) G.E. (glycerin-acetic acid, 3: 1), (ii) G.A.W. (glycerin-95\% alcohol-water, 1: 1: 1), (iii) G.A. o-T (glycerin-alcohol-o-toluidine, 2: 2: 1), (iii) G.A.An ( glycerine-alcohol-aniline, 2: 2: 1), (iv) G.A.Q. ( glycerinealcohol-quinoline, $2: 2: 1$ ).

Fragment of the lichen thallus was heaped in the center of microscope slide, and drops of acetone was added several times. After the acetone evaporates, there should be whitish or yellowish powdery ring of residue. The thallus fragments were carefully brushed away, a small drop of reagents put on a coverslip, and the coverslip placed over the residue. The slide is gently heated over an alcohol lamp, low Bunsen flame until bubbles just began to form. On cooling a few minutes, crystal began to form first around the undissolved residue, later at the perimeter of the coverslip. The shape and of the crystals were determined under a low-power microscope $(100 \mathrm{x})$, and the crystal identified by comparison with photographs. $\square$

\section{Lichen dyes}

For dyeing with lichens, three different methods were used depending to the desired color: (i) BWM-simply means "boil water method". (ii) AM-"ammonia method" and (iii) POD stand for "Photo Oxidizing Dyes". In a preliminary study, the ammonia method was used with the detailed method as follow: (i) The lichens Parmotrema tinctorum were collected from clean areas in Kamojang and then were air-dried and subjected for extra Ammoniac extraction. (ii) Six gram of thallus lichens samples were put into a glass mason jar with an airtight lid. To which 100 milliliter $(\mathrm{ml})$ of $10 \%$ ammonia $\left(\mathrm{NH}_{3}\right)$ and $100 \mathrm{ml}$ distilled water was added. (iii) Close the lid and shake vigorously. Within minutes the color shift will arise. (iv) The jar then labeled with the date, location collected and the name of species. (v) The mixed solution was fermented in the dark for 4 weeks and allowed to stand for three months and every day the jar was shaken. (vi) The monitoring of color extracts was recorded during fermentation for each week.

\section{RESULTS AND DISCUSSION}

\section{Lichen diversity}

Generally, lichens in Kamojang Geothermal areas have a high diversity consisting of more than 133 species belong to 62 genera and 17 families. Families of Parmeliaceae found in this study was dominant consisting of 33 species and the co-dominant species such as Graphidaceae and Lobariaceae with 24 species and 8 species, respectively (Table 1).

Most lichen fungi obtained in this study belong to Ascomycetes, but the fan-shaped of this lichens is a basidiomycetous lichen with cyanobacterial photobionts. It is Dictyonema sericeum (Sw.) Berk (Figure 2), which was found at Kawah Manuk area. Dictyonema is a symbiosis between a basidiomycete fungus and ascytonematoid cyanobacteria, resulted in both a basidiolichen and a cyanolichen, which is a very rare combination.

The protected species as Usnea longissima Ach. could only found in cleanest area at pinus forest in Arboretum area which $6 \mathrm{~km}$ south of Kamojang Geothermal Power Plant (Figure 2). In an effort to determine the diversity of lichens in Kamojang and to determine the species of lichen that has been utilized as medicine and dyes by the local community we performed inventory, literature study and literature process with the local community.

Lichen biodiversity is often used to assess air quality and ecosystem health within non-urban environment. This survey, in 2017 as a result in Table 1, shown one hundred thirty-three (133) species lichens have been found in Kamojang Geothermal area. But the study has been done in 1983, 1987 and 1988 lichen was found only 53 species (Noer et al. 2013). Compare to those survey, lichen in Kamojang geothermal area more diversity although the Geothermal Power Plan has operation since 1983 and produced $\mathrm{SO}^{2}$ which has been known that doses $0.018 \mathrm{ppm}$ of $\mathrm{SO}^{2}$ will kill lichens (Pearson and Skye1965; State et al. 2010; Rubio-Salcedo et al. 2017). The amazement Graphis kamojangense was found on Mangifera indica and Toena sureni trees at $0.5 \mathrm{~km}$ west and $1.5 \mathrm{~km}$ south from Geothermal Power Plan.

\section{The lichenic acid contained in genus of lichens}

Components of lichens reacting with certain test chemicals may give color reactions, which could be used in the identification of a species (Figure 3). The phytochemical screening of Usnea showed that beard moss contains alkaloid, steroid, saponin, monoterpenoid, sesquiterpenoid, quinone, and polyphenol (Choudhary et al. 2005; Fazio et al. 2007; Güllüce et al. 2006). The lichenic acid was found dominantly in Usnea are usnic acid and Stictic acid (Cansaran et al. 2006; Bessadóttir 2014). Some lichenic acids was found in several genus from Kamojang Geothermal area such as alectoronic acid, atranorin acid, barbatic acid, baeomycesis acid, chloroatranorin acid, diffrataic acid, diploicin acid, divariatic acid, gyrophoric acid, grayanic acid, haematamnolic acid, isousnic acid, lecanoric acid, leucotylin acid, lobaric acid, obtusatic acid, physodalic acid, protocetaric acid, perlatolic acid, retigeric acid, rocellic acid, salazinic acid, stenosporic acid, stictic acid, thiopanic acid and usnic acid. 
Table 1. Lichens distribution at Kamojang geothermal area, Bandung, Indonesia

\begin{tabular}{|c|c|c|c|}
\hline Species & Reproduction & Reagent & Lichen acid \\
\hline Acarospora sp. & Apothecia & - & $\begin{array}{l}\text { Norstictic acid. rhizocarpic acid } \\
\text { gyrophoric acids epanorin acids }\end{array}$ \\
\hline Amandinea punctata (Hoffm) Coppins \& Scheid & - & - & - \\
\hline Bacidia sp. & - & & No lichen substances \\
\hline Buellia punctata (Hoffm) A. Massal & Soredia and isidia & - & - \\
\hline Buellia sp.1 & Soredia and isidia & - & - \\
\hline Bulbothrix isidiza (Nyl.) Hale & Soredia and isidia & GAW & $\begin{array}{l}\text { Barbatic acid, consalazinic acid, } \\
\text { gyrophoric acid, lobaric acid, salazinic } \\
\text { acid, atranorin }\end{array}$ \\
\hline Caloplaca sp. & Soredia and isidia & - & - \\
\hline Carbacanthographis marcescens (Fée) Staiger \& Kalb & - & - & - \\
\hline Cladonia furcata (Hudson) Schrader & Soredia & GE & $\begin{array}{l}\text { Lecanoric acid fumarprotocetraric acid, } \\
\text { atranorin, divariatic acid }\end{array}$ \\
\hline Cladonia fimbriata (L.) Fr. & Soredia & GAW & Atranorin \\
\hline Cladonia mauritiana Ahti \& J.C David & Soredia & - & Sekikaic acid \\
\hline Cladonia squamosa Hoffm. & Soredia & - & $\begin{array}{l}\text { Salazinic acid, gyrophoric acid, usnic } \\
\text { acid, atranorin }\end{array}$ \\
\hline Coccocarpia palmicola (Spreng.) L. Arvidss. \& Gall. & Lobus & - & No lichen substances \\
\hline Collema nigrescens (Hudson) DC. & Soredia & - & Secondary metabolites: none detected \\
\hline Collema javanicum (Müll.Arg.) Zahlbr & Soredia & - & Secondary metabolites: none detected \\
\hline Collema pulcellum Ach. & Soredia & - & Secondary metabolites: none detected \\
\hline Coccocarpia sp. & Lobus & - & No lichen substances \\
\hline Cryptothecia striata Thor & Isidia & - & No lichen substances \\
\hline Cryptothecia sp. & Isidia & - & No lichen substances \\
\hline Chrysothrix sp. & - & - & - \\
\hline Dibaeis sp. & Soredia & - & - \\
\hline Dictyonema sericeum (Swartz) Berk. & Soredia & GE & Usnic acid \\
\hline $\begin{array}{l}\text { Diorygma junghuhnii (Mont. V. d Busch) Kalb, } \\
\text { Staiger \& Elix }\end{array}$ & Lirellae & - & - \\
\hline Dirinaria applanata (Fee) D. D. Awasthi & Isidia and soredia & - & Atranorin, divaricatic acid \\
\hline Dirinaria sp. & Isidia and soredia & - & - \\
\hline Dyplolabia sp. & - & - & - \\
\hline Flavoparmelia sp. & Soredia & - & - \\
\hline Flavopunctelia sp. & Soredia & - & - \\
\hline Fissurina elaiocarpa (A. W. Archer) & Picnidia & - & - \\
\hline Flavopunctlia soredica (Nyl.) Hale & Soredia & - & - \\
\hline Graphis sp. 1 & Lirel & - & No lichen substances \\
\hline Graphis elongate Vain. & - & - & - \\
\hline Graphis immersella Müll.Arg. & Lirel & - & Stictic acid \\
\hline Graphis kamojangense Jatnika \& Noer & Lirel & - & - \\
\hline Graphis librata C. Knight & Lirel & - & Norstictic acid \\
\hline Graphis longula Kremp. & Lirel & - & - \\
\hline Graphis rhizocola (Fée) Lücking \& Chaves & Lirel & - & - \\
\hline Graphis rustica Kremp. & Lirel & - & - \\
\hline Graphis sp. 2 & Lirel & - & - \\
\hline Graphis sp. 3 & Lirel & - & - \\
\hline Haematomma persoonii (Fee) A. Massal & Apothecia & GE & Gyrophoric acid \\
\hline Haematomma accolens (Stirton) Hillm. & Apothecia & GE & Barbatic acid \\
\hline Heterodermia japonica (Sato) Swinscow \& Krog & Soredia & GE, GAW & $\begin{array}{l}\text { Atranorin, Norsticti acid chloroatranorin; } \\
\text { zeorin, salazinic acid }\end{array}$ \\
\hline Heterodermia leucomela (L.) Poelt & Soredia & - & Salazinic acid \\
\hline Heterodermia rugulosa (Kurck.) Wetmore & Soredia & - & - \\
\hline Hypogymnia sp. 1 & Apothecia & - & $\begin{array}{l}\text { Atranorin, chloroatranorin; physodic acid, } \\
\text { physodalic acid, protocetraric acid }\end{array}$ \\
\hline Hypogymnia sp. 2 & - & - & Atranorin, physodic acid \\
\hline Hypotrachyna sp. & - & - & - \\
\hline Lecanora argentata (Ach.) Malme & - & - & - \\
\hline Lecanora helva Stizenb & - & - & Atranorin dan asam chloroatranorin \\
\hline Lecanora leprosa Fee & - & - & - \\
\hline Lecanora sp.1 & Apothecia & - & Atranorin \\
\hline Lecanora sp. 2 & & - & - \\
\hline Lepraria lobificans (Nyl.) & & - & - \\
\hline Leptogium cyanescens (Rabenh) & Lobus and soredia & - & No lichen substances \\
\hline
\end{tabular}


Letharia vulpine (L.) Hue

Lobaria pulmonaria L. (Hoffm.)

Lobaria oregano (Tuck.) Müll.Arg.

Lobaria subinterversans (Gyeln.)

Lobaria scrobiculata (Scop.) P. Gaertn.

Maronina sp.

Malcomiella sp.

Megalospora sp.1

Mycomicrothelia sp.

Megalospora sp.

Menegazzia sp.

Micarea prasina $\mathrm{Fr}$.

Niebla sp. 1

Nephroma sp.

Ocelullaria $\mathrm{sp}$

Parmelia sp.1

Parmelia sp. 2

Parmelia sp. 3

Parmeliela sp. 1

Parmelia sp. 1

Parmelia sp. 2

Parmelia sp. 3

Parmeliela sp. 2

Parmeliopsis sp.

Parmotrema cristiferum (Taylor) Hale

Parmotrema dilatatum (Vain.) Hale

Parmotrema mesotropum (Müll.Arg.) Hale

Parmotrema reticulatum (Taylor) M. Choisy

Parmotrema tinctorum (Delise ex Nyl) Hale

Parmotrema sp. 1

Pannaria sp. 1

Pannaria sp. 2

Peltigera sp. 1

Peltigera polydactylon (Necker) Hoffm

Peltigera praetextata (Florke ex Sommerf.) Zopf

Pertusaria sp. 1

Pertusaria cicatricose Müll.Arg.

Pertusaria texana Müll.Arg.

Pertusaria sp. 2

Pertusaria sp. 3

Phaeographis adinoconspicua (Fée) Müll.Arg.

Phaeographis dendritica (Ach.) Müll.Arg.

Phaeographis dendroides (Leight.) Müll.Arg.

Phaeographis intricans Nyl.

Phaeographis lobata (Eschw.) Müll.Arg.

Phaeographis schizoloma (Müll.Arg.)

Paeographis sp.

Physcia sp.

Pseudocyphellaria aurata (Ach.) Vain.

Pseudocyphellaria crocata (L.) Vain.

Pseudocyphellaria sp.

Psora pseudorusellii

Pyrenula subdunata

Pyrenula sp.1

Pyxine sp. 1

Pyxine sp. 2

Ramalina celastri (Spreng.) Krog \& Swinscow

Ramalina farinacea (L.) Ach.

Ramalina pollinaria (Westr.) Ach.
Lobus and

apothecia

Lobus and soredia

Lobus and soredia

Lobus

Apothecia

Apothecia

Soredia

Soredia

Pseudothecia $\square$

Isidia and soredia

Soredia and isidia

Soredia and isidia

Soredia and isidia

Apothesia

Soredia and isidia

Soredia and isidia

Soredia and isidia

Apothesia

Soredia and isidia

Soredia

soredia

Cilia and soredia

Soredia

\section{Cilia and soredia}

-

Lobus and soredia

Lobus and soredia

Lobus and soredia

Perithesia

Perithesia

Perithesia

Perithesia

Perithesia

Lirel

Lirel

Lirel

Lirel

Lirel

Lirel

Lirel

Soredia and isidia

Lobus

Lobus

Lobus

Soredia and isidia

Perithesia

Apothesia

Soredia

Soredia

Soredia
Stictic Acid, desmethyl stictic acid, gyrophoric acid, tenuiorin, constictic acid, norstictic acid, peristictic acid, and methylnorstictic acid

Methylstictic acid, crypto-stictic acid, cryptostic-tinolide.

Barbatic acid

Zeorin acid

GAW Zeorin acid

Barbatic acid, Stictic acid

GAW

Atranorin, Lecanoric acid

Atranorin

Atranorin

Atranorin, Lecanoric acid

Atranorin

Atranorin

Atranorin and chloroatranorin; salazinic acid and consalazinic acids

Atranorin, chloroatranorin, salazinic acid and consalazinic acids

Lecanoric acid, atranorin

Salazinic acid, Atranorin, Lecanoric acid

Tenuiorin, dolichorrhizin, zeo-rin, methyl gyrophate, gyrophoric acid,

Stictic acid

Stictic acid, constictic acid

$-$

Barbatic

Lecanoric acid

Gyrophoric acid

Barbatic acid

GAW

$-$

GAAn, GAW Barbatic acid, usnic acid, salacinic acid, gyroporic acid

GAAn, GAW Barbatic acid, usnic acid

GE, GAW

GE

Iso-usnic acid and usnic acid

Usnic acid

Usnic acid 
Ramalina sp.

Relicina mallesiana(Hale) Hale

Relicina sp. 1

Relicina sp. 2

Rhizocarpon sp.

Sarcographa cinchonarum Fee

Sarcographa tricosa (Ach.) Mull. Arg.

Stereocoulon sp.

Sticta dissimulate

Sticta lingulata Vain.

Teloschistes flavicans (Sw.) Norman

Usnea articulate (L.) Hoffm

Usnea baileyi (Stirton) Zahlbr.

Usnea ceratina Ach.

Usnea dasypoga (Ach.) Shirley

Usnea subfloridana Stirton

U. flexilis Stirt

Usnea hirta (L.) Weber ex F.H Wigg.

Usnea trichodea Ach.

$\begin{array}{lll}\text { Soredia } & \text { GAW } & \text { Iso-usnic acid and usnic acid } \\ \text { Soredia } & - & - \\ \text { Soredia } & - & - \\ \text { Soredia } & - & - \\ \text { Perithesia } & \text { GE } & \text { Rhizocarpic acid } \\ \text { Hysterothesia } & \text { GE } & \text { Stictic acid } \\ \text { Hysterothesia } & \text { GAAn } & \text { Salazinic acid, stictic acid, evernic acid } \\ \text { Apothecia } & & \text { Decanoic acid } \\ \text { Picnidia and soredia } & - & \text { Gyrophoric acid } \\ \text { Picnidia and soredia } & - & \text { Gyrophoric acid } \\ \text { Pseudothesia } & - & \text { Parietin, teloschistin, parietinic acid } \\ & & \text { caloploicin } \\ \text { Isidia and } & \text { Barbatik, physodalic, lecanoric, physodalic } \\ \text { pseudothesia } & \text { GAW } & \text { Chloroatranorin } \\ \text { Isidia and } & \text { GE } & \text { Usnic acid } \\ \text { pseudothecia } \square & \text { GAoT } & \text { Grayanic, diffractaic } \\ \text { Isidia and } & \text { GAW } & \text { Usnic acid } \\ \text { pseudothecia } \square & \text { GAoT } & \text { Divaricatic } \\ & \text { GE } & \text { Gyrophoric, lobaric, isousnic } \\ \begin{array}{l}\text { Isidia and } \\ \text { pseudothecia } \square\end{array} & \text { GAW } & \text { Usnic acid, diffractaic acid } \\ \text { Isidia and } \\ \text { pseudothecia } \square\end{array}$

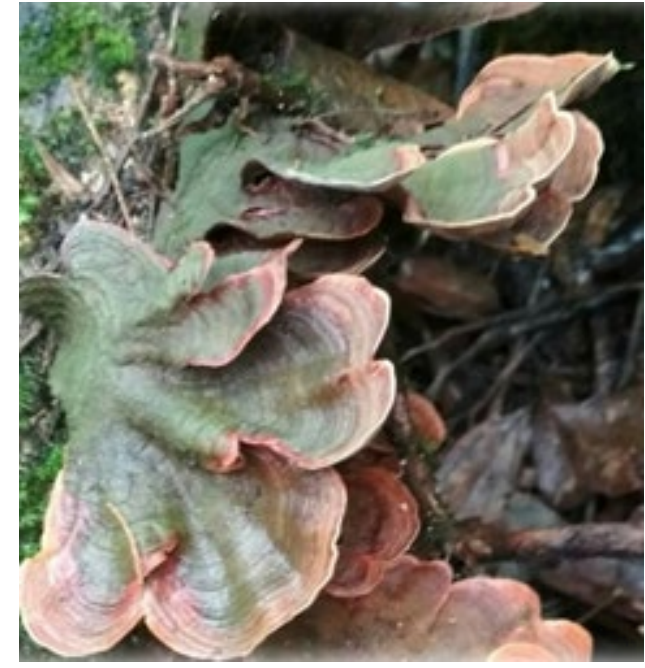

A

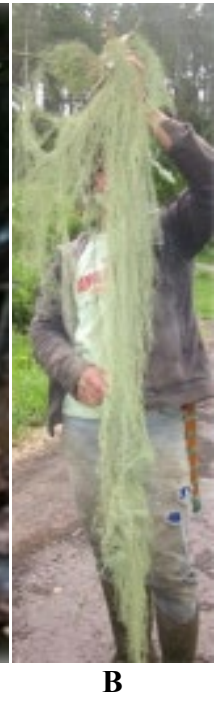

B
Figure 2. Rare lichens. A. Dictyonema sericeum (Sw.) Berk, B. Usnea longisima Ach

In general lichens in Kamojang geothermal area contains atranorin, usnic acid, gyrophoric and barbatic (Tabel 1). Those lichenic acid has reported are have potential for medicinal properties (Ashina and Shibata 1954; Cobanoglu et al. 2010; Crawford 2015). Such as usnic acid and salizilic acid were used for antiinflammation and analgesic action, and usnic acid has used as antifungal

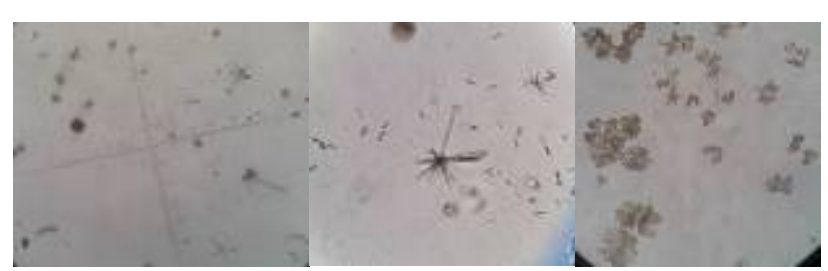

A

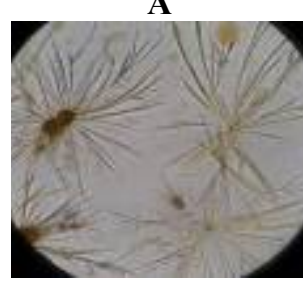

D
B

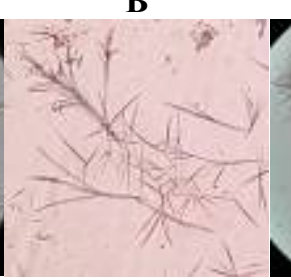

$\mathbf{E}$

\section{C}

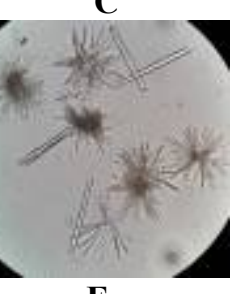

$\mathbf{F}$
Figure 3. Several displays of lichen's acid crystals: A. Atranorin acid, B. Barbatic acid, C. Baeomycesis Acid (G.A.An), D. Gyrophoric acid (G.E), E. Lecanoric acid (GE), F. Usnic acid (G.E)

and antibiotic (Rankovic et al. 2008; 2007b). Beside that isodivaricatic, 5-propylresorcinol acid, divaricatinic acid and usnic acid which are contained in Usnea florida var. rigida. Acharius have proven good for antimicrobial activity against fungi Microsporum gypseum, Trichophyton rubrum and Trichophyton mentagrophytes growth (Fazio et al. 2007; Kekuda et al. 2016). Usnic acid showed also 
significant antibacterial activity against Bacillus cereus, $B$. megaterium, Staphylococcus aureus and Klebsiella pneumoniae (Saenz et al. 2006; Kukeda et al. 2016).

Atranorin isolated from lichen demonstrated an approximate and relatively strong antimicrobial activity against bacteria Bacillus mycoides, B. subtilis, Staphylococcus aureus, Enterobacter cloacae, Escherichia coli, Klebsiella pneumoniae and fungi Aspergillus flavus, A. fumigatus, Botrytis cinerea, Candida albicans, Fusarium oxysporum, Mucor mucedo, Paecilomyces variotii, Penicillium purpurescens, $P$. verrucosum, Trichoderma harzianum (Ranković et al. 2007a, 2007b; 2008; Kukeda et al. 2016). It is reported that Acarospora, contain norstictic acid. rhizocarpic acid gyrophoric acids epanorin acids. These acid have reported inhibit from the growing of $B$. subtilis and S. aureus (Rezanka and Guschina 1999)

So, from 133 species found in Kamojang Geothermal Area, there are, twenty-three (23) genus have been identified as medicine lichens. The genus has possible good potentially for medicine base on literature study were Acarospora, Bulbothrix, Cladonia, Collema, Coccocarpia,
Flavoparmelia, Graphis, Heterodermia, Hypogymnia, Leptogium, Lobaria, Lecanora, Lasallia, Nephroma, Parmotrema, Pseudocyphellaria, Peltigera, Parmelia, Pertusaria, Physcia, Ramalina, Sticta, and Usnea

Lichens have been used in traditional medicine since the time of the first Chinese and Egyptian civilizations (Chopra 1958; Noer 2013). Their utilization in folklore as medicine has been cited in different pharmacopeias of the world (cf. Nisyapuri et al. 2018). During the middle-ages lichens figured prominently among the herbs used by medicinal practitioners (Hale 1983). The use of lichens in medicine can be traced back to antiquity. Evernia furfuracea has been found in an Egyptian vase belongs to $18^{\text {th }}$ Dynasty (1700-1600 BC) was used as a drug (Crawford 2015; Lal 1990). The literature review and records of medicinal plant lore of Indonesia show the word 'janggot kai, rusuk angin and kayu angin' are used for lichen Usnea for long time ago, a text where the first authentic record of 'jamu' (medicine) has been described (Noer 2013). The Java names of "rusuk angin" were later identified to several species of Parmelioid lichens, such as

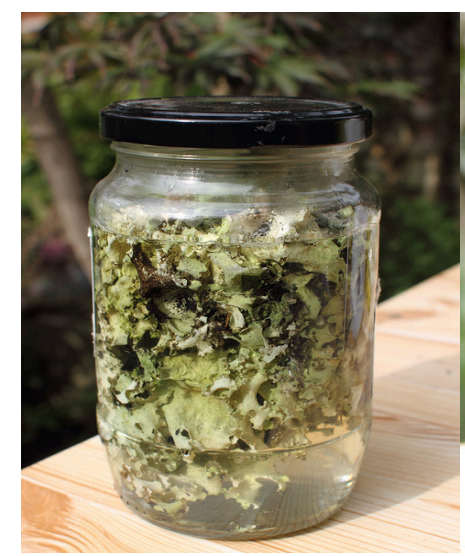

A

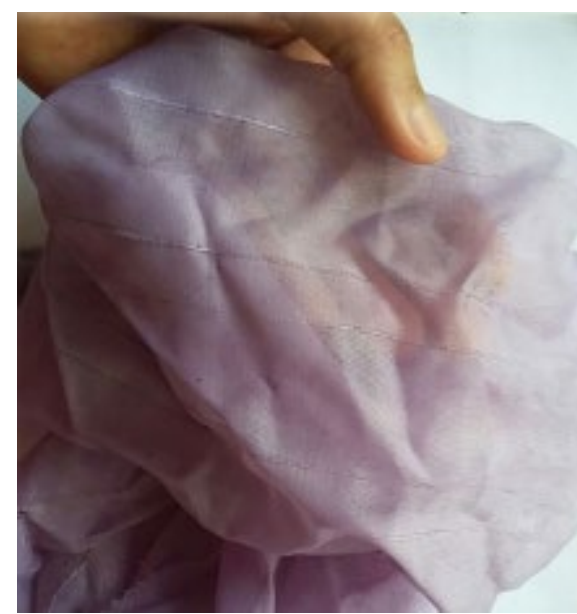

$\mathbf{E}$

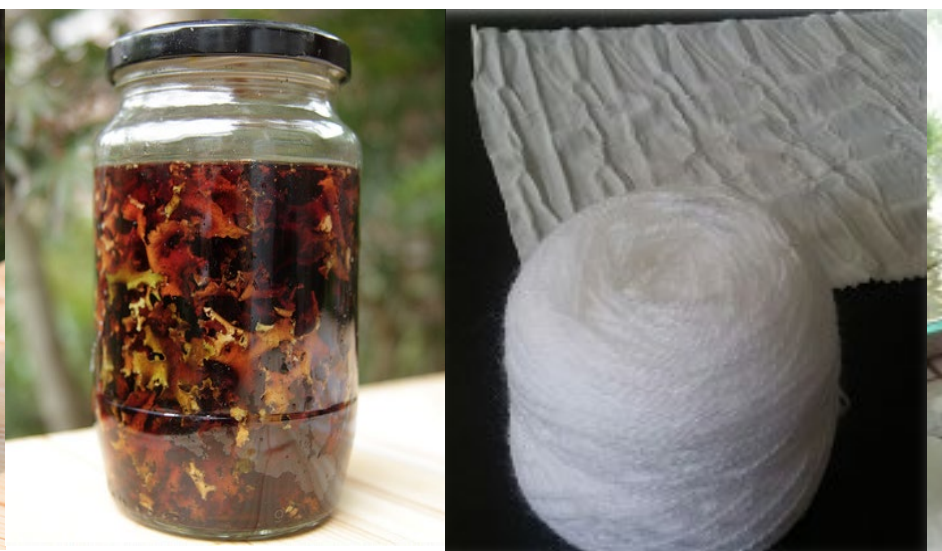

B

C

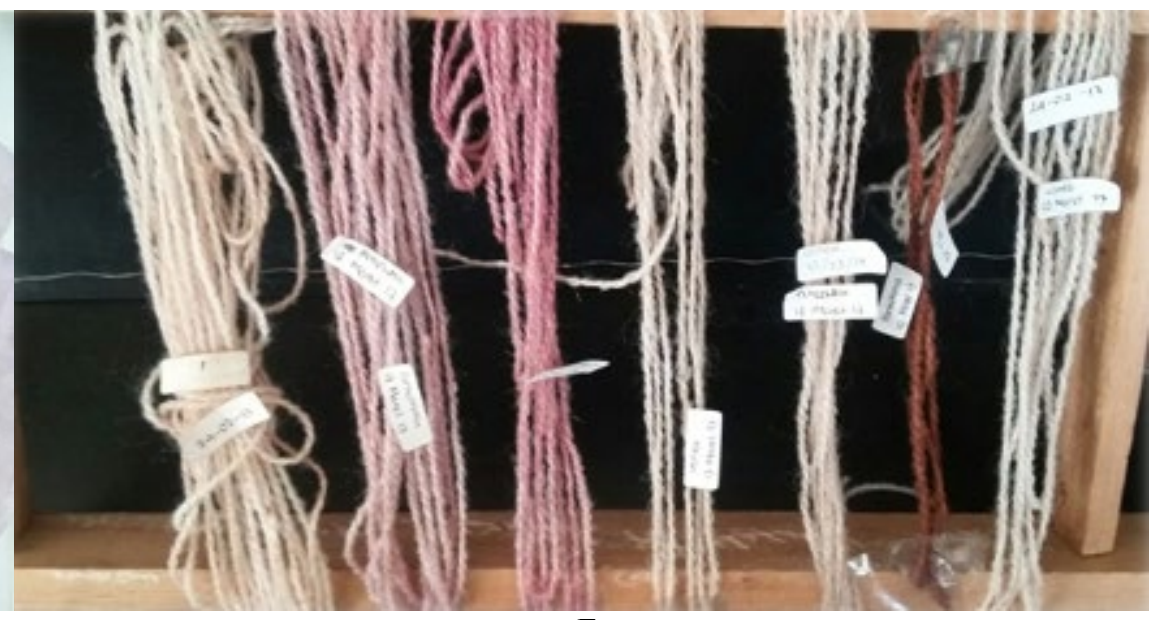

D

$\mathbf{F}$

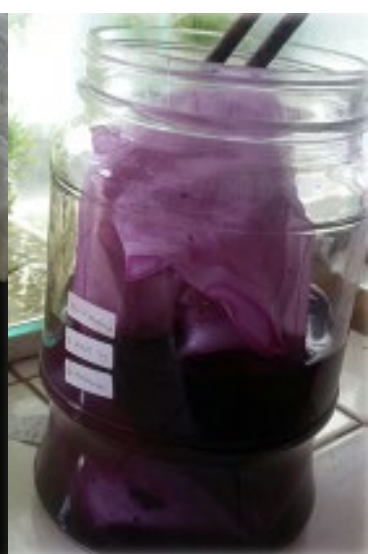
. 
Usnea longisima. U. barnata, U. missamensis. U. dasypoga and Telosichtes. The vernacular name jamu widely used in Indonesian traditional medicine, an ancient system of locally Indonesia medicine, for different disease and disorders, for example, headache, skin diseases, urinary trouble, boils, vomiting, diarrhea, dysentery, heart trouble, cough, fever, leprosy and as a blood purifier.

\section{Lichen dyes}

Dye colors produced from Parmotrema tinctorum using ammoniac extracts were brownish red, dark red and purple. The color change of Parmotrema tinctorum ammoniac extracts occurred after $1^{\text {st }}$ until $3^{\text {rd }}$ weeks of fermentation. $P$. tinctorum had brownish red in $1^{\text {st }}$ week and dark red after $3^{\text {rd }}$ week of fermentation. Purple colors occurred in $4^{\text {th }}$ week and dark violet color had been stable since $5^{\text {th }}$ week of fermentation. While Usnea spp., produced brown color dyes and various brown since 5 days of fermentation up to $4^{\text {th }}$ week. Base on the literature study, lichens at Kamojang geothermal area which has potential for dyes are Parmotrema, Usnea, Lobaria, Peltigera, and Hypogymnia.

Ammonia fermentation methods (AFM) is the best method to get a wide range of colors such as pink, violet, orange, grey, brown and yellow. Livelihoods natural dyes from lichens Parmotrema very interesting and will be important in the use of dyes that are environmentally friendly in industry that would reduce the pollution of water/river by dyes from industry. $\square$

In Ammonia extraction, lichens that have a $\mathrm{C}+$ response are best for purple and violet dyes (Allen 2014). Spot test has done to Parmotrema spp. giving respond $\mathrm{C}+$ red. Parmotrema tinctorum ammoniac extracts produced greyish violet. This was in accordance with studies by Casselman and Terada (2012) who stated that $P$. tinctorum produced purple color on fabric and thread through ammoniac fermentation. Such different colors shown from lichen ammoniac extracts were related to compounds in the lichen. Produced colors indicated the presence of particular compounds in Parmotrema tinctorum and Usnea baileyi species that reacted with ammoniac and aquadest.

Purple color was produced presumably due to lecanoric acid in the Parmotrema tinctorum species. Lecanoric acid is p-depside that were hydrolyzed to orselic acid and undergoes a series of chemical reaction to form 'orcein' color precursor (Shukla et al. 2014). Salgado et al. (2018) reported that Parmotrema contains gyrophoric acid. It has been used as a purple and red dye for thousands of years, mainly in the northern hemisphere

\section{ACKNOWLEDGEMENTS}

We thanks to Pertamina and PLN and People in Kamojang for providing the field facilities, The Lichens group of Biology for their assistance in collecting specimens, Dr. Felix Schumm and Dr. Andre Aptroot for their assistance during analysis and identification. Dr. Robert Lucking for correction and support the new species of Graphis. This paper publication is supported by ALG
(Academic Leadership Grant) of Ethnobiology for Public Welfare in Support Sustainable Development. Therefore, authors would like to thank Rector of Padjadjaran University, Prof. Tri Hanggono Achmad has supported the publication.

\section{REFERENCES}

Allen A. 2014. Getting started with lichen dyes. Fungi 7: 2-3.

Ardelean IV, Keller C, Scheidegger C. 2015. Effects of management on lichen species richness, ecological traits and community structure in the Rodnei Mountains National Park (Romania). PLoS ONE 10(12): e0145808. https://doi.org/10.1371/journal.pone.0145808

Asahina Y, Shibata S. 1954. Chemistry of lichen substances. Japan Society for the Promotion of Science, Tokyo.

Balabanova B, Stafilov T, ̌ajn RS, "eva KB. 2014. Comparison of response of moss, lichens and attic dust to geology and atmospheric pollution from copper mine. Int J Environ Sci Technol 11:517-528.

Bayir Y, Odabasoglu F, Cakir A, Aslan A, Suleyman H, Halici M, Kazaz C. 2006. The inhibition of gastric mucosal lesion, oxidative stress and neutrophil infiltration in rats by the lichen constituent diffractaic acid. Phytomedicine 13(8): 584-590.

Bessadóttir M. 2014. The Effects of the Lichen Metabolites Usnic Acid and Protolichesterinic Acid on Energy and Lipid Metabolism in Cancer Cells. [Dissertation] Faculty of Medicine, University of Iceland, Reykjavik, Iceland.

Cansaran D, Kahya D, Yurdakulol E, Atakol A. 2006. Identification and quantification of usnic acid from the lichen Usnea species of Anatolia and antimicrobial activity. Zeitschrift für Naturforschung 61 (11): 773-776.

Casselman KD, Terada T. 2012. The politics of purple: D yes from Shellfish and Lichens. Textile Society of America. $13^{\text {th }}$ Biennial Symposium, September 19-22, 2017. Washington DC. $\square$

Chopra RN, Chopra IC, Handa KL. Kapur LD. 1958. Indigenous drugs of India. Academic Publishers, Calcutta and New Delhi.

Choudhary MI, Azizuddin, Jalil S. An, Rahman A. 2005. Bioactive phenolic compounds from a medicinal lichen, Usnea longissima. Phytochemistry 66 (19): 2346-2350.

Cobanoglu G, Sesal C, Gkmen B, Cakar S. 2010. Evaluation of the antimicrobial properties of some lichens. Southwest J Hortic Biol Environ 1 (2): 153-158.

Crawford SD. 2015. Lichens Used in Traditional Medicine. In Rankovic 'B. (ed.), Lichen Secondary Metabolites. Springer International Publishing Switzerland.

Fazio AT, Adler MT, Bertoni MD, Sepúlveda CS, Damonte EB, Maier MS. 2007. Lichen secondary metabolites from the cultured lichen mycobionts of Teloschistes chrysophthalmus and Ramalina celastri and their antiviral activities. Zeitschrift für Naturforschung 62 (7-8): 543-9.

Güllüce M, Aslan A, Sokmen M, Sahin F, Adiguzel A, Agar G, Sokmen A. 2006. Screening the antioxidant and antimicrobial properties of the lichens Parmelia saxatilis, Platismatia glauca, Ramalina pollinaria, Ramalina polymorpha and Umbilicaria nylanderiana. Phytomedicine 13 (7): 515-521.

Gupta VK, Darokar MP, Saikia D, Pal A, Fatima A, Khanuja SPS. 2007. Antimycobacterial activity of lichens. Pharmaceutical Biol 45 (3): 200-204.

Hale ME. 1983. The biology of lichens. $3^{\text {rd }}$ Edition. Edward Arnold Ltd. London.

Ingólfsdóttir K, Gudmundsdóttir GF, Ögmundsdóttir HM, Paulus K, Haraldsdóttir S, Kristinsson H, Bauer R. 2002. Effects of tenuiorin and methyl orsellinate from the lichen Peltigera leucophlebia on 5/15-lipoxygensases and proliferation of malignant cell lines in vitro. Phytomedicine 9: 654-658.

Kaasalainen U. 2012. Cyanobacteria and Their Toxins in Lichen Symbiosis. [Dissertation] Department of Biosciences Faculty of Biological and Environmental Sciences University of Helsinki. Helsinki.

Kekuda TRP, Mesta AR, Vinayaka KS, Darshini SM, Akarsh S. 2016. Antimicrobial Activity of Usnea ghattensis G. Awasthi and Usnea undulata Stirt. J Chem Pharm Res 812): 83-88. 
Lal B. 1990. Ethnobotanical Studies of the Baiga Tribe of Madhya Pradesh. [Thesis]. Meerut University, Meerut.

Malhotra S, Subban R, Singh A. 2007. Lichens-Role in Traditional Medicine and Drug Discovery. Internet J Alternative Med 5 (2): 1-6.

Nisyapuri FF, Iskandar J, Partasasmita R. 2018. Study of ethnobotany of medicinal plants in Wonoharjo Village, Pangandaran Regency, West Java. Pros Sem Nas Masy Biodiv Indon. 4 (2): 122-132. [Indonesian]

Noer SI, Ramlan A, Subarnas A, Sutedja E. 2013. Characterization and relationship bear moss (Usnea spp.) at Priangan. Indonesian J Appl Sci 3 (2):66-73

Noer SI, Rani RI. 2007. The culture of Indonesian lichen talii of Usnea flexuosa. Simposium kebudayaan Indonesia-Malaysia X, 29-31 May 2007. Universiti Kebangsaan Malaysia, Selangor DE. [Indonesian]

Noer SI, Shinta I, Sri H. 2006. Taxonomy and bioassay of Usnea baileyi (Stirt.) Zahlbr as a dermatophytosis antifungal which is prospective in the future. [Research report]. Research Institute of Padjadjaran University, Bandung. [Indonesian].

Noer SI. 2013. Study of Lumut Janggut (Usnea spp.) In East Priangan. [Dissertation], Padjadjaran University, Bandung. [Indonesian].

Onuț-Brännström I. 2017. The puzzle of lichen symbiosis. Pieces from Thamnolia. [Dissertation] Faculty of Science and Technology. Acta Universitatis Upsaliensis. Uppsala.

Pearson L, Skye E. 1965. Air pollution effects pattern of photosynthesis in Parmellia sulcata a corticulous lichen. Sci 148: 1600-1602.

Ranković B, Mišić M, Sukdolak S. 2007a. Evaluation of antimicrobial activity of the lichens Lasallia pustulata, Parmelia sulcata, Umbilicaria crustulosa and Umbilicaria cylindrica. Mikrobiologya 76 (6): 817-821.

Ranković B, Mišić M, Sukdolak S. 2008. The antimicrobial activity of substances derived from the lichens Physcia aipolia, Umbilicaria polyphylla, Parmelia caperata and Hypogymnia physodes. World J Microbiol Biotechnol 24: 1239-1242.

Ranković B, Mišić S, Sukdolak S. 2007b. Antimicrobial activity of extracts of the lichens Cladonia furcata, Parmelia caperata, Parmelia pertusa, Hypogymnia physodes and Umbilicaria polyphylla. British J Biomedical Sci 64 (4): 143-148.

Rezanka T, Dembitsky VM. 2006. The colleflaccinosides, two chiral bianthraquinone glycosides with antitumor activity from the lichen Collema flaccidum collected in Israel and Russia. Nat Product Res 20 (10): 969-80.

Řezanka T, Guschina IA. 1999. Brominated depsidones from Acarospora gobiensis, a lichen of Central Asia. J. Nat. Prod. 62: 1675-1677.

Rubio-Salcedo M, Psomas A, 'a Prieto M, Zimmermann NE, 'nez IM. 2017. Case study of the implications of climate change for lichen diversity and distributions. Biodivers Conserv 26:1121-1141.

Saenz MT, Garcia MD, Rowe J. G. 2006. Antimicrobial activity and phytochemical studies of some lichens from south of Spain. Fitoterapia 77 (3): 156-159.

Salgado F, Albornoz L, Cortéz C, Stashenko E, Urrea-Vallejo K, Nagles 1E, Galicia-Virviescas C, Cornejo A, Ardiles A, Simirgiotis M, García-Beltrán O, Areche C.2018. Secondary metabolite profiling of species of the genus Usnea by UHPLC-ESI-OT-MS-MS. Molecules 23 (1):1-16; doi:10.3390/molecules23010054.

Shukla P, Upreti DK, Nayaka S, Tiwari P. 2014. Natural dyes from Himalayan lichens. Indian J Traditional Knowledge. 13 (1): 195-201.

State G, Popescu IV, Gheboianu A, Radulescu C, Dulama I, Bancuta J, Stirbescu R. 2010. Lichens as biomonitors of heavy metal air pollution in the Targoviste area. J Sci Arts 1 (12): 119-124.

Tarasova VN, Obabko RP, Himelbrant DE, Boychuk MA, Stepanchikova IS, Borovichev EA. 2017. Diversity and distribution of epiphytic lichens and bryophytes on aspen (Populus tremula) in the middle boreal forests of Republic of Karelia (Russia). Folia Cryptog Estonica Fasc. 54: 125-141.

Vartia KO. 1973. Antibiotics in lichens. In The Lichens (Eds. Ahmadjian V, Hale ME.). Academic Press. New York and London.

Vicol, I. 2016. Ecological patterns of lichen species abundance in mixed forests of Eastern Romania. Ann. For. Res. 59(2): 237-248. 